\title{
Parenting Styles as Correlates of Adolescents Drug Addiction among Senior Secondary School Students in Obio-Akpor Local Government Area of Rivers State, Nigeria
}

Onukwufor, Jonathan $\mathrm{N}^{1}$ iD
Chukwu, Mercy Anwuri ${ }^{2}$ iD
${ }^{1}$ Department of Educational Psychology Guidance and Counseling University of Port Harcourt
Port Harcourt Rivers State, Nigeria
Nigeria

\begin{abstract}
The study was conducted to find out the relationship between parenting styles and secondary students drug addiction among adolescents in secondary schools in Obio-Akpor Local Government Area (L.G.A.) of Rivers State Nigeria. The study was guided by three research questions and similar number of null hypotheses. The study adopted a correlation research design. The population of the study consisted of all the 12,000 senior secondary students in thirteen public secondary schools in Obio-Akpor L.G.A. The study had a sample of 1200 students. A proportional stratified sampling technique was used to draw the sample size. Two instruments called Parenting Styles Questionnaire (PSQ) and Adolescent Drug Addiction Questionnaire (ADAQ) were used for the study. The instruments face and content validities were determined. The reliability coefficients of the two instruments were 0.93 for PSQ and 0.89 for ADAQ respectively. Correlation statistics by Pearson was used to answer the research questions, and test the null hypotheses. Result of the study among others is that authoritarian and authoritative parenting styles have a very low positive relationship with adolescents' drug addiction. It was recommended among others that parents, counselors, teachers and all those involved in character formation should try and be more authoritative in their attitude towards children, especially the adolescents.
\end{abstract}

Keywords: Parenting styles, Drug addiction, Adolescents, Psychoactive-drugs, Psychopharmacology.

\section{Contents}

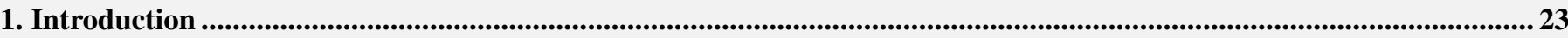

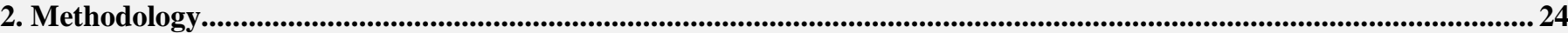

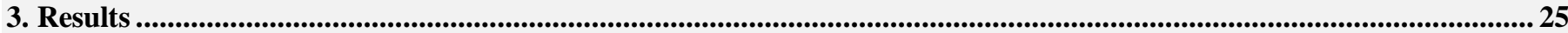

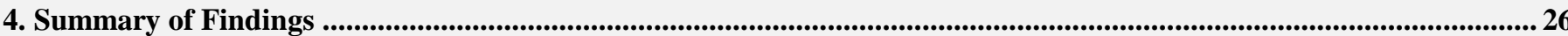

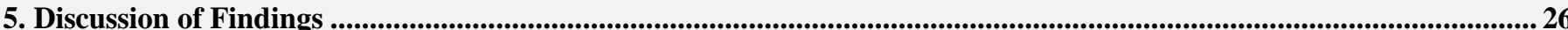

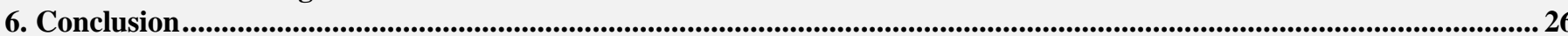

7. Recommendations.........................26 26

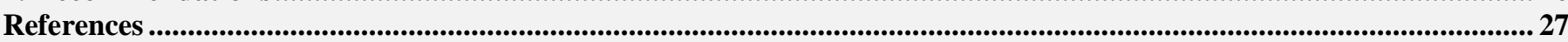

Citation | Onukwufor, Jonathan N; Chukwu, Mercy Anwuri (2017). Parenting Styles as Correlates of Adolescents Drug Addiction among Senior Secondary School Students in Obio- Akpor Local Government Area of Rivers State, Nigeria. Journal of Education and e-Learning Research, 4(1): 22-27.

DOI:

$\operatorname{ISSN}(\mathbf{E}):$

10.20448/journal.509.2017.41.22.27 crossref

Licensed: 2518-0169

This work is licensed under a Creative Commons Attribution 3.0 License $(\mathrm{cc})$ E

Contribution/Acknowledgement: Both authors contributed to the conception and design of the study.

Funding:

This study received no specific financial support.

Competing Interests:

Transparency:

The authors confirm that the manuscript is an honest, accurate, and transparent account of the study was reported; that no

Ethical: vital features of the study have been omitted; and that any discrepancies from the study as planned have been explained.

Publisher:

This study follows all ethical practices during writing.

Asian Online Journal Publishing Group 


\section{Introduction}

Parenting could be seen as the process of promoting and supporting the physical, emotional, social, financial, and intellectual development of a child from infancy to adulthood. Parenting refers to the aspects of raising a child aside from the biological relationship (Davies, 2000).

Parenting style is the term psychologists use to describe how parents rear their children through behavior, discipline, and methods used that influence children (Kordi and Baharudin, 2010). Research tends to show that the overall parenting style is more influential for determining the child's future conduct than the specific behaviors used.

According to Spera (2005) parenting style is a psychological construct representing standard strategies that parents use in their child upbringing. A parent can spend an entire afternoon with his child, yet the parent may be engaged in a different activity and not demonstrating enough concern towards the child. Parenting styles are the representation of how parents respond and place demand on their children. The relationship between the parent and the child is attachment. In the stage of adolescence, parents encounter new challenges, such as adolescents seeking and desiring freedom (Querido et al., 2002).

\subsection{Concept of Drug Addiction}

Drug in this context is an illegal substance that people smoke or inject to give them pleasant or exciting feelings (Sally, 2000). Similarly, Bernstein et al. (2006) stated that 'a drug is a chemical that is not usually needed for physiological activity and that can affect the body upon entering it. The definition of a drug therefore suggests that drug is a kind of chemical which affects the body when it enters the body and that is not indispensable. Colman (2003) stated that addiction is a state of dependency on a chemical substance especially on drugs such as alcohol, nicotine, caffeine, or a narcotic such as morphine or heroin characterized by strong physiological or psychological need. According to Colman, addiction also involves a compulsive inability to resist taking the drug despite anticipation of probable adverse consequence of withdrawal if there is an abrupt deprivation of the drug. The greater danger of drug abuse is drug addiction. Implicit in drug addiction is that the addict finds it extremely difficult to refrain from the consumption of such drug even at the detriment of the adolescents physiological, psychological, cum social well being.

Drug abuse according to Akinade (2005) is 'the use of a drug in a way that is not in accordance with the recommended medical use of the drug'. Akinade further stipulated that the drugs are mainly those that affect the brain and mind by depressing, stimulating or disorganizing it. Such drugs are often referred to as hard drugs and they include drugs such as cocaine, marijuana, and heroin. Some soft drugs which people are addicted to include: coffee, alcohol, kola nut and aspirin. At this juncture, it is imperative to state that hard drugs which affect the brain change human consciousness and other psychological processes are called psychoactive drugs, while the study of psychoactive drugs is called psychopharmacology (Bernstein et al., 2006)

According to Morris et al. (2007) the commonly used psychoactive drugs could be grouped into three categories namely; Depressants which include: alcohol, barbiturates and Opiates; the second group, stimulants include: caffeine, Nicotine, amphetamines and cocaine, while the last group is made up, of hallucinogens and marijuana. Morrris, Maisto and Dunn further highlighted that depressants slow down behavior and cognitive process, while stimulants speed up mental processes especially those controlled by sympathetic nervous system. On the other hand, hallucinogens trigger significant distortions of various mental processes especially perception (Morris et al., 2007)

Drug abuse leads to drug addiction. Drug addiction is formally known as substance dependence which refers to a maladaptive pattern of substance use that causes a person significant distress or substantially impairs that person's life (Passer and Smith, 2004)

Drug addiction among adolescents is undesirable and is one of the major problems of adolescents. Drug addiction among adolescents is undesirable because it could lead to failure and school dropout which may subsequently induce the adolescent to engage in diverse forms of anti-social behaviors such as rape, kidnapping, armed robbery and murder. Drug addiction could as well elicit health problems such as cancer, schizophrenia, high blood pressure and sudden death. Perhaps it was in the light of the above that Nwankwo (2003) stated that the excessive use of substance is seen as a disorder because it has adverse effects on the physical, psychological and physiological integrity of the user.

\subsection{Concept of Adolescent}

An adolescent is a person who is developing from a child into an adult. Adolescence is between the age of 13 and 18 (Sally, 2000). At the period of adolescence they form personal identity, test and develop inter personal and occupational roles that they will later assume as adults. It is therefore imperative for parents to treat adolescents with special regard. According to Meakin (2013) a teenager who thinks poorly of himself, is not confident, hangs around with gangs, lacks positive values, follows the crowd, is not doing well in studies, loses interest in school, has small number of friends, lacks home supervision or is not close to significant adults like parents and is vulnerable to peer pressure. Parents often feel alone and isolated in parenting adolescents, thus parents are expected to endeavor to be aware of their adolescents' activities, and to provide guidance, direction, and consultation. During the period of adolescence the young people spend more time with their peers and less time with parents. Gilbert et al. (2011) stated that peer pressure is not the reason why peers have influence on adolescents; instead, it is often because they respect, like and admire their peers. Parental constraints at this period of raising adolescence include: handling rebellious teenagers who were unaware of freedom when they were children.

\subsection{Types of Parenting Styles}

Through Baumrind's research, two characteristics of parenting styles were found: control or demanding and responsiveness or child centeredness (Baumrind, cited in Bernstein et al. (2006)). Parental responsiveness means the support and love which a child got from parents, while demanding refers to behavioral control (Terry, 2004). Baumrind created the three parenting styles commonly used today from those traits which are: permissive, 
authoritarian, and authoritative (Bernstein et al., 2006). The three ways of raising children could be described thus: permissive parenting involves low control and high level of responsiveness; authoritarian parents are high in control and low in responsiveness; and authoritative parenting involves high level of control and responsiveness. The styles of parenting can predict a child's behavior, which includes social competence, academic performance, psychosocial development and problem behaviors (Terry, 2004).

An authoritative style of parenting mainly results when there is high parental responsiveness and high parental demands, O'Byrne et al. (2002). Authoritative parents normally set specified standards for their off springs, monitor the limits which they set, and allow their children to develop independence. They also expect mature autonomous and age-related appropriate behavior from their children. Consequently, children from authoritative parenting homes are more likely to be successful, well-liked by people around them, generous and capable of self-determination (Strassen, 2011).

Authoritarian parenting is a restrictive, punishment-heavy parenting style in which parents make their children adhere to their directions with little to no explanation or feedback and focus on the child's and family's perception and status (Santrock, 2007).

Children who are brought up authoritarian parents appear to be conformist, highly obedient, calm, and not very happy most of the time. These children often suffer from depression and self-blame (Strassen, 2011).

- For some children brought up by authoritarian parents, these behaviors continue into adulthood.

- Children who are resentful of or angry about being raised in an authoritarian environment but have strived to develop high behavioral self-confidence often rebel in adolescence and/or young adulthood (Strassen, 2011).

According to Santrock (2007) Indulgent parenting is a style of parenting in which parents are very involved with their children but place few demands or controls on them (Santrock, 2007). Indulgent parents are nurturing and accepting, and are responsive to the child's needs and wishes. The children often grow into adulthood not accustomed to other people aggression due to their inappropriate up-bringing which would be a great shock to them. As adults, they pay less attention in avoiding behaviors which cause aggression to others. 2014).

Permissive parents do not play parental role to their children rather they try to be "friends" to them (Rosenthal,

Children of permissive parents may tend to be more impulsive and as adolescents may engage more in misconduct such as drug use (Prange, 2014). Children of permissive parents never learn to control their own behavior and always expect to get their way (Santrock, 2007). But positively, they are emotionally secure, independent and are willing to learn and accept defeat. They mature quickly and are able to live life without the help of someone else (Dornbusch, 2007).

\subsection{Statement of the Problem}

Realizing the uncomfortable trend of most societal ills being associated with the youths; Government, Religious bodies, traditional communities and educational institutions, the media and non-governmental organizations have embarked on series of campaigns and teachings against youths involvement in such behaviors. Researches have shown that today's armed robbers are teenagers and young adults in their early twenties. The level of drug addiction among the youths may be quite alarming and would have contributed to high rate of cultism, HIV/AIDS infections and other societal vices. These are of great concern to the researchers and the society. Many factors have been identified as being responsible for these behaviors. The family being the first agent of socialization and training of the child cannot be left out in this search. It has been noticed that even in the places where these perversions are prevalent some youths have been able to resist all the peer pressures to stay free from these vices. Sometimes it has been observed that whereas children from some families are totally notorious for these vices, some from other families are totally free. There is therefore a strong reason to take a look at the relationship between parenting styles and adolescents drug addiction. The focus of this research therefore is to find out the relationship between parenting styles and adolescents drug addiction in Obio-Akpor L.G.A of Rivers State.

\subsection{Research Questions}

1. This research work sought to provide answers to the following research questions:

2. What is the relationship between authoritative parenting style and drug addiction among senior secondary school students in Obio-Akpor L.G.A of Rivers State?

3. What is the relationship between authoritarian parenting style and drug addiction among senior secondary school students in Obio-Akpor L.G.A of Rivers State?

4. What is the relationship between permissive parenting style and drug addiction among senior secondary school students in Obio-Akpor L.G.A of Rivers State?

\subsection{Hypotheses}

1. There is no significant relationship between authoritative parenting style and adolescents' drug addiction among senior secondary school students in Obio-Akpor L.G.A of Rivers State.

2. There is no significant relationship between authoritarian parenting style and adolescents' drug addiction among senior secondary school students in Obio-Akpor L.G.A of Rivers State.

3. There is no significant relationship between permissive parenting style and adolescents' drug addiction among senior secondary school students in Obio-Akpor L.G.A of Rivers State.

\section{Methodology}

This study adopted a correlation research design. Nwankwo (2013) stated that whenever a researcher is interested in finding out whether there is a relationship between two or more variables, and data from such variables are in ratio 
or interval scale (score) to create the possibility for the scores to be correlated, such is a correlation design. The population of the study is all the 12,000 Senior Secondary School Students in thirteen public schools in Obio/Apkor L.G.A of Rivers State. Source: (Rivers State Ministry of Education, Statistics and Planning Unit: 2015). A proportional stratified random sampling technique was used to draw a sample size of 1200 SSS students. Two instruments were used for the study. They are self-designed instruments titled Parenting Styles Questionnaire (PSQ) and Adolescents' Drug Addiction Questionnaire (ADAQ). The two instruments were structured after the modified Likert four points of strongly Agree 4, Agree 3, Disagree 2 and strongly Disagree 1. The instruments contain 40 items (30 items for PSQ and 10 items for ADAQ). Face and content validities were ensured through the help of three experts in the area of Educational Psychology, measurement and evaluation in the University of Port Harcourt. The Cronbach reliability statistics was used to establish the reliability of PSQ and ADAQ. The general reliability coefficient is 0.93, Authoritative 0.63, Authoritarian 0.93, Permissive 0.74 and Drug Addiction 0.89 respectively. The Pearson product moment correlation with the help of statistical package in social sciences (SPSS) was used to answer the research questions and the null hypotheses at 0.05 alpha level.

\section{Results}

The result of the research questions and null hypotheses are as follows:

\section{Research Question One}

What is the relationship between authoritative parenting style and drug addiction among senior secondary school students in Obio-Akpor Local Government Area of Rivers State?

\section{Hypothesis One}

There is no significant relationship between authoritative parenting style and drug addiction among senior secondary school students in Obio-Akpor Local Government Area of Rivers State.

Table-1. Pearson Product moment correlation analysis on the relationship between authoritative parenting style and drug addiction among senior secondary school students in Obio-Akpor Local Government Area of Rivers State

\begin{tabular}{l|l|l|l|l}
\hline Variables & N & r & Sig. & Remark \\
\hline Authoritative parenting style & & & & Not statistically significant \\
\cline { 1 - 4 } drug addiction & 1200 & 0.368 & 0.50 & \\
\hline
\end{tabular}

Source: Field Work (2017)

Table 1 revealed that the Pearson Product Moment coefficient $r$ is given as 0.37 . This implies that there is a low positive relationship between authoritative parenting style and drug addiction among senior secondary school students in Obio/Akpor L.G.A. The calculated probability value of 0.50 is greater than the critical probability p-value of 0.05 , therefore, the null hypothesis is accepted. By implication, there is no significant relationship between authoritative parenting style and drug addiction among senior secondary school students in Obio/Akpor Local Government Area of Rivers State.

\section{Research Question Two}

What is the relationship between authoritarian parenting style and drug addiction among senior secondary school students in Obio-Akpor L.G.A of Rivers State?

\section{Hypothesis Two}

There is no significant relationship between authoritarian parenting style and drug addiction among senior secondary school students in Obio-Akpor Local Government Area of Rivers State.

Table-2. Pearson Product moment correlation calculation on the relationship between authoritarian parenting style and drug addiction among senior secondary school students in Obio-Akpor Local Government Area of Rivers State

\begin{tabular}{l|l|l|l|l}
\hline Variables & N & R & Sig. & Remark \\
\cline { 1 - 4 } Authoritarian parenting style & \multirow{2}{*}{1200} & 0.029 & 0.31 & Not statistically significant \\
\hline drug addiction & &
\end{tabular}

Source: Field Work ( 2017)

Table 2 revealed that the Pearson Product Moment coefficient $r$ is given as 0.03 . This implies that there is a low positive relationship between authoritarian parenting style and drug addiction among senior secondary school students in Obio-Akpor L.G.A. The calculated probability value of 0.31 is greater than the critical probability p-value of 0.05 , therefore, the null hypothesis is accepted. By implication, there is no significant relationship between authoritarian parenting style and drug addiction among senior secondary school students in Obio-Akpor Local Government Area of Rivers State.

\section{Research Question Three}

What is the relationship between permissive parenting style and drug addiction among senior secondary school students in Obio-Akpor L.G.A. of Rivers State?

\section{Hypothesis Three}

There is no significant relationship between permissive parenting style and drug addiction among secondary school students in Obio-Akpor L.G.A. of Rivers State. 
Table-3. Pearson Product moment correlation analysis on the relationship between permissive parenting style and drug addiction among senior secondary school students in Obio-Akpor Local Government Area of Rivers State

\begin{tabular}{l|l|l|l|l}
\hline Variables & N & r & Sig. & Remark \\
\hline permissive parenting style & \multirow{2}{*}{1200} & & & Statistically significant \\
\hline drug addiction & Source Field Work (2017) & 0.84 & 0.00 & \\
\hline
\end{tabular}

Source Field Work (2017)

Table 3 revealed that the Pearson Product Moment coefficient $r$ is given as 0.84 . This implies that there is a high positive relationship between permissive parenting style and drug addiction among senior secondary school students in Obio/Akpor L.G.A. The calculated probability value of 0.00 is less than the critical probability value of 0.05 , therefore, the null hypothesis is rejected. By implication, there is a significant relationship between permissive parenting style and drug addiction among senior secondary school students in Obio-Akpor Local Government Area of Rivers State.

\section{Summary of Findings}

Based on the analysis of data collected, the following findings were made:-

1) There was a low positive relationship between authoritative parenting style and drug addiction among senior secondary school students in Obio-Akpor Local Government Area of Rivers State.

2) There was a low positive relationship between authoritarian parenting style and drug addiction among senior secondary school students in Obio-Akpor L.G.A.

3) There was a high positive relationship between permissive parenting style and drug addiction among senior secondary school students in Obio-Akpor L.G.A.

4) There was no significant relationship between authoritative parenting style and drug addiction among senior secondary school students in Obio-Akpor Local Government Area of Rivers State.

5) There was no significant relationship between authoritarian parenting style and drug addiction among senior secondary school students in Obio-Akpor Local Government Area of Rivers State.

6) There was a significant relationship between permissive parenting style and drug addiction among senior secondary school students in Obio-Akpor Local Government Area of Rivers State.

\section{Discussion of Findings}

The findings of this study are discussed as shown below.

\subsection{Authoritative Parenting Style and Drug Addiction}

The finding showed that there was a low positive relationship between authoritative parenting style and drug addiction among senior secondary school students in Obio-Akpor Local Government Area of Rivers State. The finding of this study was in agreement with Querido et al. (2002) when they reported that authoritative parenting was associated with less disruptive behavior in a sample of 3 to 6 year old. This goes a long way to explain the fact that authoritative parenting style has a low relationship with disruptive behavior or drug addiction.

\subsection{Authoritarian Parenting style and Drug Addiction}

The finding also showed that there was a low positive relationship between authoritarian parenting style and drug addiction among senior secondary school students in Obio-Akpor L.G.A. this is in contrast with the finding of Odubote (2008) that authoritarian parenting style was highly correlated with delinquency behaviour, adding that the authoritative parenting style has been associated with positive outcomes.

\subsection{Permissive Parenting Style and Drug Addiction}

The finding showed that there was a high positive relationship between permissive parenting style and drug addiction among senior secondary school students in Obio-Akpor L.G.A. This finding is in tandem with Prange (2014) and Adalbjarnardottir and Hafsteinsson (2001) that parental permissiveness or indulgence was also associated with increased adolescent alcohol and tobacco use.

\section{Conclusion}

Based on the findings of this study, it was concluded that authoritarian and authoritative parenting styles have low positive relationship with adolescents' drug addiction while permissive has high positive relationship with adolescents' drug addiction in senior secondary schools in Obio-Akpor L.G.A of Rivers State. This implies that in order to mitigate adolescents' drug addiction, parents should adopt authoritative parenting style in bringing up their children and eschew permissive parenting style.

\section{Recommendations}

1. It is recommended that parents, counselors, teachers and all those involved in character formation should try and be more authoritative in their attitude towards children, especially the adolescents.

2. Creation of a suitable environment for child rearing and provision of the child's need may prevent the development of depressive mood which may lead to drug addiction.

3. Parents should not adopt permissive parenting style in the upbringing of their children as it has the highest propensity to drug addiction. 


\section{References}

Adalbjarnardottir, S. and L.G. Hafsteinsson, 2001. Adolescents' perceived parenting styles and their substance use: Concurrent and longitudinal analyses. Journal of Research Adolescent, 11(4): 401-423. View at Google Scholar $\mid$ View at Publisher

Akinade, E.A., 2005. Dictionary of guidance and counselling. Ibadan: Olu-Akin Publishers.

Bernstein, D.A., L.A. Penner, A. Clarke-Stewart and E.J. Roy, 2006. Psychology. 7th Edn., Boston: Houghton Mifflin Company

Colman, A.M., 2003. A dictionary of psychology. New York: Oxford University Press.

Davies, M., 2000. The Blackwell encyclopaedia of social works. Oxford: Wiley-Blackwell.

Dornbusch, S.M., 2007. Patterns of competence and adjustment among adolescents from authoritative, authoritarian,indulgent, and neglectful families. Child Development, 62: 1049-1065. View at Google Scholar | View at Publisher

Gilbert, D.T., D.L. Schacter and D.M. Wegner, 2011. Psychology. New York: Worth Publishers.

Kordi, A. and R. Baharudin, 2010. Parenting attitude and style and its effect on children's school achievements. International Journal of Psychological Studies, 2(2): 217-222. View at Google Scholar | View at Publisher

Meakin, N., 2013. The pros and cons of sharenting. The Guardian. [Accessed 2014].

Morris, C.G., A.A. Maisto and L.W. Dunn, 2007. Psychology: Concept and applications. New Jersey: Pearson Education, Inc.

Nwankwo, O.C., 2003. Psychological basis of counselling and adolescence perspective. Port Harcourt: University of Port Harcourt Press.

Nwankwo, O.C., 2013. A practical guide to research writing for students of research enterprise. 5th Edn., Port Harcourt: Pam Unique Publishers Co. Ltd.

O’Byrne, K.K., C.K. Haddock and W.S. Poston, 2002. Parenting style and adolescent smoking. Journal of Adolescent Health, 30(6): 418-425. View at Google Scholar | View at Publisher

Odubote, B.A., 2008. Parenting style, race and delinquency: A comparative study of European American. African American and Nigerian Families. ProQuest.

Passer, M.L. and R.E. Smith, 2004. Psychology, the science of mind and behaviour. 2nd Edn., New York: McGraw Hill.

Prange, M., 2014. Clinical psychology child and family psychology. Retrieved from www.drmarkprange.com [Accessed 7 December 2014].

Querido, J., T. Warner and S. Eyberg, 2002. Parenting styles and child behaviour in African American families of preschool children. Journal of Clinical Child Psychology, 31(2): 272, 227. View at Google Scholar | View at Publisher

Rosenthal, M., 2014. Knowing yourself and your children. Maryann Rosenthal. Retrieved from www.drma.com [Accessed 10 October 2014].

Sally, W., 2000. Oxford advanced learners dictionary of current english. 6th Edn.: Oxford University Press.

Santrock, J.W., 2007. A topical approach to life-span development. 3rd Edn., New York: McGraw-Hill.

Spera, C., 2005. A review of the relationship among parenting practices, parenting styles, and adolescent school achievement. Educational Psychology Review, 17(2): 125-146. View at Google Scholar $\mid$ View at Publisher

Strassen, B.K., 2011. The developing person through the life span. Worth Publishers.

Terry, D.J., 2004. Investigating the relationship between parenting styles and delinquent behaviour. McNair Scholars Journal: Regulated Learning. Journal of Educational Psychology, 11:314-332. View at Google Scholar 